\title{
TRANSFER KNOWLEDGE: SUBMIT ARTIKEL PADA JURNAL ONLINE BERBASIS OJS UNTUK IPELMAS
}

\section{Triyanto', Nodi Marefanda ${ }^{2}$, Arfriani Maifizar ${ }^{3}$, Nurkhalis$^{4}$, Akmal Saputra5, Rahma Husna Yana ${ }^{6}$, Yeni Sri Lestari ${ }^{7}$}

\author{
1,3,4,5,6, 7Prodi Sosiologi, Universitas Teuku Umar \\ Email: Triyanto@utu.ac.id \\ Email: Arfrianimaifizar@utu.ac.id \\ Email: Nurkhalis@utu.ac.id \\ Email: Akmalsaputra@utu.ac.id \\ Email: Rahmahusnayana@utu.ac.id \\ Email: $\underline{\text { YenniSrilestari@utu.ac.id }}$
}

2Prodi Administrasi Negara, Universitas Teuku Umar

Email: nodimarefanda@utu.ac.id

Revised: 03-07-2020

Accepted: 03-07-2020

\begin{abstract}
The existence and quality of higher education nowadays can be influenced by the high and low levels of scientific work owned by lecturers and students. This scientific work becomes very important in the existence and quality of tertiary institutions because it's ranking at the national and international level is calculated on the ownership of the scientific work. So it is not surprising that BAN-PT as an external quality assurance institution which also has the task of assessing the accreditation of higher education also includes its assessment on this matter. Thus higher education that is technically operational at the study program level also pressures lecturers and students to be productive, which is to produce as much scientific work as possible. Even some lecturers provide requirements for students to write a scientific paper when they want to propose a thesis session. However, the number of scientific works owned by lecturers and students will not mean anything when not published in a journal that uses an open journal system. This emphasis lies in the open journal system, where the meaning will be far different from online journals. In general, not many students understand how to submit scientific papers in the form of articles to the open journal system there are still many lecturers who do not understand the process in the open journal system. For this reason, knowledge transfer in the form of technical training to submit articles in the online journal system is carried out. The main goal is to provide knowledge and insight into submitting articles. The results of the activity show the progress of understanding and knowledge, this is proven by simulations through the application of OJS version 2.4.8 which is used for the training process by the participants.
\end{abstract}

Keywords: articles, scientific papers, journals, online, OJS, submit papers

\begin{abstract}
Abstrak
Eksistensi dan kualitas perguruan tinggi saat ini dapat dipengaruhi oleh tinggi rendah dan banyak atau sedikitnya karya ilmiah yang dimiliki dosen dan mahasiswanya. Karya ilmiah ini menjadi sangat penting dalam eksistensi dan kualitas perguruan tinggi karena rankingnya di level nasional maupun internasional dihitung kepemilikan karya ilmiah tersebut. Sehingga tidak heran juga BAN-PT sebagai institusi penjaminan mutu eksternal yang juga memiliki tugas
\end{abstract}


menilai akreditasi perguruan tinggi juga mencantumkan penilaiannya mengenai hal ini. Dengan demikian perguruan tinggi yang secara teknis pelaksanaan operasional dilakukan di level prodi juga menekan dosen dan mahasiswanya untuk produktif, yakni menghasilkan karya ilmiah sebanyak-banyaknya. Bahkan sebagian dosen memberikan persyaratan bagi mahasiswanya untuk menulis sebuah karya ilmiah ketika ingin mengusulkan sidang skripsinya. Namun, banyaknya karya ilmiah yang dimiliki dosen dan mahasiswa tersebut tidak akan berarti apapun ketika tidak dipublikasikan dalam sebuah jurnal yang menggunakan open journal system. Penekanan ini terletak pada open journal system, dimana maknanya akan jauh berbeda dengan jurnal online. Pada umumnya mahasiswa belum banyak yang memahami tentang bagaimana melakukan submit karya ilmiah berupa artikel ke dalam open journal system, bahkan masih banyak didapati dosen yang belum memahami proses yang ada dalam open journal system. Untuk itu transfer knowledge berupa pelatihan teknik submit artikel pada sistem jurnal online ini dilakukan. Tujuan utamanya adalah memberikan pengetahuan dan wawasan dalam melakukan submit artikel. Hasil kegiatan menunjukkan kemajuan pemahaman dan pengetahuan, hal ini dibuktikan dengan simulasi melalui aplikasi OJS versi 2.4.8 yang digunakan untuk proses latihan oleh peserta.

Kata Kunci: artikel, karya ilmiah, jurnal, online, OJS, submit paper

\section{PENDAHULUAN}

Ranking menjadi sesuatu yang sangat penting bagi perguruan tinggi baik negeri maupun swasta. Bukan hanya yang ada di Indonesia saja tetapi juga semua yang ada di seluruh dunia ini. Bahkan saling mengejar dan berlomba mencari posisi ranking yang tertinggi. Posisi dalam ranking memiliki gengsi tersendiri, khususnya ketika sebuah perguruan tinggi baru mampu menduduki ranking yang lebih baik dengan perguruan tinggi yang memiliki usia lebih lama.

Lebih bergengsi lagi ketika ranking tersebut diumumkan di media yang dapat diakses masyarakat umum seperti publikasi ranking webometrics yang menyebutkan ranking beberapa perguruan tinggi di Indonesia dimana Universitas Indonesia masih menjadi perguruan tinggi terbaik di Indonesia karena menempati ranking satu (Prayogo, 2020). Hal ini bukan hanya sekedar memberikan gengsi saja, tetapi juga memberikan kepercayaan masyarakat terhadap institusi perguruan tinggi sesuai posisi rankingnya. Hal seperi ini juga akan memainkan perasaan bagi civitas akademika pada kampus yang dipandang memiliki ranking rendah, seperti dicontohkan bagaimana perasaan seorang mahasiswa atau dosen ketika seorang teman di kampus lain yang kebetulan memiliki ranking lebih tinggi sering menceritakan keunggulan kampusnya tidak peduli menurut / berdasarkan kriteria dari webometrics atau lembaga lain. Kondisi seperti ini 
bisa membuat perasaan malu bahkan marah.

Untuk itu, sangat wajar jika kemudian semua kampus juga tampak seolah berlomba-lomba mengejar ranking yang lebih baik. Salah satu pintu bagi kampus untuk mendapatkan ranking adalah dengan banyaknya karya ilmiah yang dimuat dalam sebuah journal dan terindeks oleh google scholar, scopus, crossref, Garuda, DOAJ dan lain-lain. Menurut Zaenuri, Suhada, \& Widanigsih indeksasi yang sering digunakan dalam acuan penelitian seorang dosen atau peneliti adalah scopus, google scholar, dan sinta dikti (Sudiar and Latiar, 2020). Sementara Hazrati menyebut bahwa keberadaan jurnal sendiri berfungsi untuk menginformasikan capaian hasil penelitian (Rahmawati, 2018). Namun, hal tersebut di atas juga harus dibarengi dengan kemampuan menulis mahasiswa dan dosen, ini sangat penting dalam meningkatkan kualitas pendidikan (Pahmi et al., 2018).

Permasalahan paling mendasar bagi sebuah jurnal agar terindeks adalah harus menggunakan aplikasi open journal system (OJS). Aplikasi OJS ini menekankan pada proses penerbitan dengan melewati tahapan-tahapan tertentu yang melibatkan tiga komponen penting yaitu editor yang terdiri dari berbagai macam bagian (section, copy edit, dan layout), author, dan profreader. Herlawati menyebutkan diantara keunggulan aplikasi OJS ini adalah merupakan open sourse sehingga mudah diakses dan disitasi (Herlawati, 2017).

Namun, penggunaan OJS belum lengkap untuk kepentingan eksistensi kampus, karenanya selain penggunaan OJS karya ilmiah tersebut juga harus berkualitas. Kualitas karya ilmiah salah satunya berkaitan dengan unsur plagiasi. Sering penulis karya ilmiah baik sengaja atau tidak terjebak dalam kasus plagiasi, hal ini terjadi terkadang disebabkan oleh karena minimnya pengetahuan tentang teknik-teknik pengutipan atau cara melakukan sitasi (Hasanah et al., 2019).

Selain itu, penulis dalam menuangkan karya ilmiahnya juga harus mengikuti kaidah-kaidah penulisan yang baik (Rahmawati et al., 2018). Dengan demikian maka karya ilmiah akan terpublish dengan baik dan menghasilkan sitasi yang juga akan mendorong kampus mencapai target rankingnya.

Namun, masih banyak dijumpai mahasiswa dan dosen yang belum memahami sistem pengiriman karya ilmiah pada sebuah jurnal yang memiliki basis open journal system. Ketidakpahaman ini akan mengakibatkan tertolaknya sebuah 
artikel padahal secara kualitas isi karya ilmiah sangat baik dan menarik, bahkan mampu menyumbangkan bagi pengembangan keilmuan tertentu.

Berdasarkan hal tersebut di atas maka sangat penting untuk membuat kegiatan berupa transfer knowledge yang difokuskan pada submit artikel pada jurnal berbasis OJS kepada kelompok Ikatan Pelajar dan Mahasiswa Simeulue (IPELMAS), yang memiliki semangat tinggi untuk menimba pengetahuan sebanyak-banyaknya di luar daerah. Kegiatan ini bertujuan untuk membekali dan memberikan pengetahuan tentang teknik-teknik melakukan submit artikel dan mengawal sampai terbit.

\section{METODE PELAKSANAAN}

Dalam pelaksanaan kegiatan ini dilakukan koordinasi dengan berbagai pihak. Pihak pertama adalah Ikatan Pelajar dan Mahasiswa Simeulue (IPELMAS). Dalam hal ini organisasi ini telah mengusulkan diri dan mengagendakan kegiatan ini. Banyak diantaranya adalah mahasiswa Program Studi Sosiologi, sehingga organisasi ini meminta dukungan Program Studi Sosiologi sebagai pihak berikutnya untuk mengirimkan dosen sebagai tim fasilitator yang melakukan transfer knowledge dalam bentuk sosialisasi.

Komunikasi dua pihak ini bersambut karena pihak prodi sedang memfasilitasi kebutuhan dosen yang sedang melaksanakan kegiatan aktualisasi. Akhirnya kesepakatan terjadi dengan menentukan waktu, sistem kegiatan, dan tempatnya.

Sistem kegiatan dilakukan melalui model sosialisasi, namun memungkinkan dikembangkan dalam bentuk pelatihan. Selain itu, diperbolehkan jika ada masyarakat atau mahasiswa selain anggota Ipelmas mengikuti kegiatannya, sehingga kegiatan bersifat umum yang bisa diikuti siapa saja.

\section{HASIL DAN PEMBAHASAN}

Kegiatan dilaksankan di tempat BeToKnow Coffe yang terletak di daerah Rundeng belakang SMA Muhammadiyah Meulaboh. Dalam kegiatan tersebut diikuti oleh sejumlah 15 orang mahasiswa baik anggota maupun non anggota Ipelmas. Kegiatan berlangsung dari pagi sampai dengan siang hari yang diisi beberapa materi berkaitan.

Rincian beberapa materi berkaitan dengan karya ilmiah tersebut dapat dilihat dalam tabel berikut ini: 
Tabel 3.1: Kegiatan dan Pemateri

\begin{tabular}{|c|l|c|c|}
\hline No. & \multicolumn{1}{|c|}{ Acara } & Waktu & Pemateri \\
\hline 1. & Pengenalan jurnal online & $08.00-08.30$ & Akmal Saputra \\
\hline 2. & Jurnal online di UTU & $08.31-09.00$ & Nodi Marefanda \\
\hline 3. & Submit Artikel pada OJS & $09.00-10.00$ & Triyanto \\
\hline 4. & Peer Review OJS & $10.30-11.00$ & Arfriani Maifizar \\
\hline 5. & Jurnal mahasiswa & $11.30-12.00$ & Nurkhalis \\
\hline
\end{tabular}

Pada susunan materi di atas memiliki penekanan materi yang berbeda-beda sehingga peserta mampu memahami kaitan antara materi satu dengan lainnya dalam sistem penerbitan jurnal online yang menggunakan open journal system.

Materi pertama tentang Universitas Teuku Umar (UTU) pengenalan jurnal online yang pada saat ini dapat diakses memberikan gambaran tentang secara online. Penekanan materi ini pembedaan antara jurnal online adalah bahwa UTU memberikan dengan open journal system. Jurnal referensi-referensi bagi para penulis, online dimaksudkan sebagai jurnal peneliti, termasuk dosen dan yang sudah dapat diakses dimana saja dan kapan saja, sehingga tidak ada batasan waktu yang dapat menghambat pembaca dalam mengakses data jurnal kecuali faktor buruknya jaringan internet dan fasilitas perangkat yang rusak. Dengan adanya jurnal online maka jurnal yang sebelumnya dicetak dengan kertas dapat disebarluaskan secara online sehingga dalam hal ini dipandang memiliki fungsi keuntungan seperti mudah diakses , dapat dikaji ulang, ada penghargaan bagi penulis, bisa menjadi bahan rujukan (Hazrati, 2017).

Materi kedua menekankan kondisi fasilitas jurnal di mahasiswa yang membutuhkan rujukan dalam penulisannya. Rujukan sangat penting dalam penulisan sebuah karya ilmiah, hal ini bermanfaat bukan hanya sekedar menyediakan sumber rujukan saja namun juga berkaitan dengan tingkat plagiasi tulisan seseorang. Artinya untuk menghindari atau meminimalisir plagiasi diperlukan rujukan untuk memastikan bahwa apa yang dihasilkan sudah atau belum ditulis orang lain. Nah, yang paling dekat adalah tulisan - tulisan yang diarsipkan dalam jurnal jurnal yang sudah ada di UTU. Berdasarkan informasi dalam laman SINTA saat ini sudah terdapat 14 jurnal yang sudah online serta 
menggunakan

OJS

(http:/ / sinta.ristekbrin.go.id/,

2020).

Ditekankan kepada peserta oleh karena hampir semua Ipelmas merupakan mahasiswa dari UTU maka diharapkan mampu memanfaatkan semaksimal mungkin jurnal - jurnal tersebut. Selain memanfaatkan untuk mengambil rujukan juga diharapkan dapat berkontribusi dalam penulisan dengan cara berkolaborasi dengan dosen.

Materi ketiga membahas mengenai teknik submit atau pengiriman naskah ke dalam jurnal yang berbasis OJS. Sebelum membahas teknik submit juga disampaikan penjelasan mengenai skill yang diperlukan dalam pengelolaan jurnal online berbasis OJS. Perubahan jurnal non OJS menjadi OJS diperlukan keterampilan khusus bagi pengelola jurnal (Darmalaksana dan Suryana, 2017).

Materi ketiga ini menekankan bahwa seorang author atau penulis yang mengirimkan artikelnya pada jurnal online berbasis OJS harus terus memantau perkembangan jurnalnya. Setidaknya author akan menyelesaikan 5 (lima) tahapan dalam proses submit sampai dengan publish. Peserta langsung diberikan materi ini dengan mengikuti alur submit yang dilakukan seorang author seperti dalam bagan alur berikut ini:

Bagan alur ini merupakan langkah-langkah yang harus dilalui seorang author dalam mengirimkan naskah artikelnya.

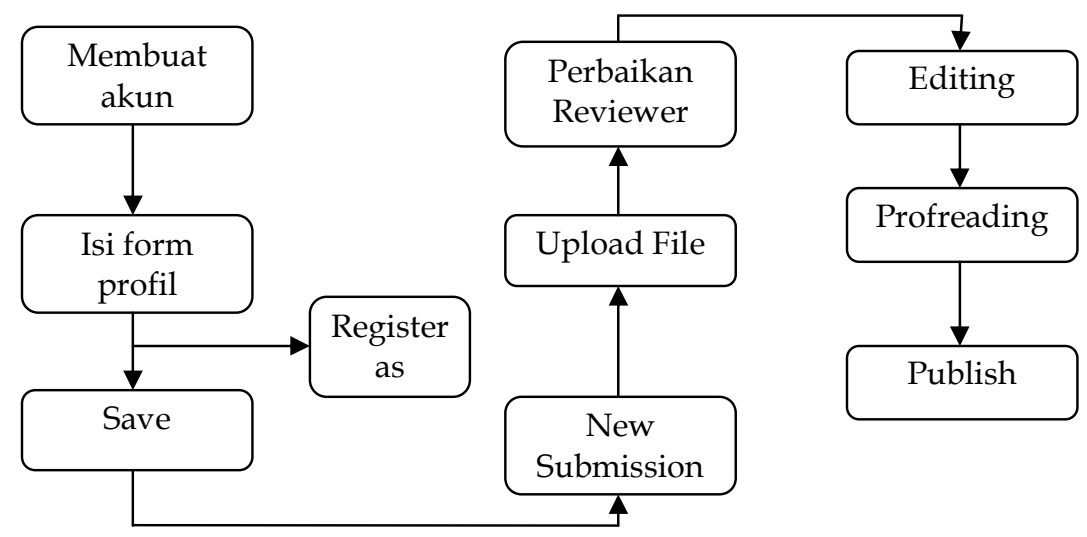

Gambar 1: Bagan alur submit naskah pada OJS 
Pada bagan ini 5 (lima) tahapan yang dimaksudkan di atas adalah pada tahap sign up (membuat akun), submit (new submission), perbaikan sesuai arahan reviewer, tahap editing, dan tahap profreading.

Pada tahap pertama membuat akun harus dilakukan seorang penulis ketika akan melakukan submit naskah. Namun, naskah yang ditulis oleh beberapa author akunnya hanya dilakukan oleh salah satu saja. Untuk hal ini memungkinan juga penulis kedua atau lainnya menjadi korespondensi. Korespondensi disini adalah author yang akan bertanggungjawab melakukan pengiriman naskah, perbaikan naskah dan memproses sampai dengan naskah terpublish sebagai finalisasi dari submit submission (Darmalaksana dan Suryana, 2017).
Tahap kedua adalah new submission, yaitu tahap dimana author mengirimkan naskahnya. Beberapa hal yang perlu diperhatikan adalah syarat - syarat yang harus dipenuhi seperti naskah belum pernah dipublikasikan oleh pihak manapun, file yang dikirimkan mengikuti format dokumen yang berlaku pada jurnal (ms word, rtf, dan lain - lain ). Pada jurnal berbasis OJS pada umumnya hanya menerima naskah dalam format dokumen.doc (Ms. Word), .rtf, .xml, html (Mathar, 2017).

Pada beberapa jurnal berbasis OJS, ketentuan tersebut tampak pada poin kedua submission ceklist sebagaimana pada gambar berikut ini:

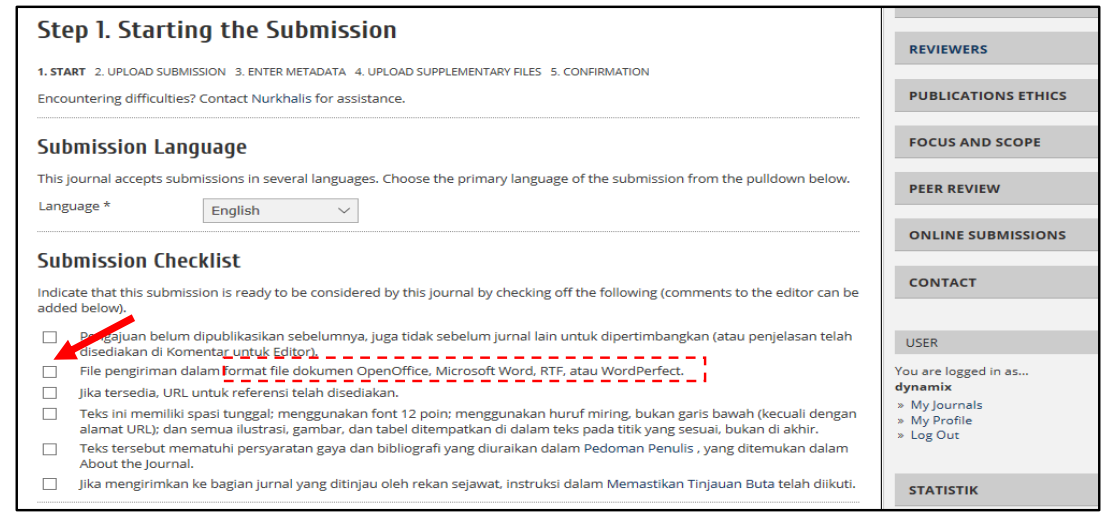

Gambar 2: Submission ceklist yang wajib dipenuhi author

Tahap ketiga dari kewajiban author adalah memperbaiki naskah yang sudah di-review oleh seorang reviewer. Secara sederhana reviewer bisa dikatakan sebagai seorang ahli dalam keilmuannya yang bertugas 
melakukan seleksi naskah yang berkualitas dan layak untuk penerbitan jurnalnya (Darmalaksana dan Suryana, 2017).

Pada tahap ini apabila naskah dianggap sangat baik dan reviewer memutuskan tidak ada perbaikan, seorang section editor akan langsung meneruskan pada tahap berikutnya yaitu editing. Artinya salah satu kewajiban seorang author tidak perlu dilakukan karena naskahnya dianggap sudah baik.

Tahap keempat adalah tahap editing, dimana author harus memperbaiki naskah dan harus disesuaikan dengan template yang sudah ditentukan oleh pengelola jurnal. Pada umumnya terjadi salah paham oleh author dalam memandang beberapa bagian dari template, bahkan bisa jadi author tidak memperhatikan template yang sudah ditentukan. Akan tetapi jika penulisan sudah sesuai dengan template, copy editor yang ditunjuk oleh section editor tidak akan meminta author untuk memperbaiki. Namun pada tahap ini author bisa upload naskah yang memang sudah sesuai dengan template. Apabila naskah tidak diunggah, maka proses bisa terhenti. Jika memang naskah sudah baik dan proses terhenti karena author lupa tidak membuka akun, maka proses bisa digantikan oleh editor in chief atau journal manager.

Tahap kelima, adalah proses profreading, dimana sebelumnya layout editor atas perintah section editor sudah melakukan penyusunan naskah, memberikan label halaman, volume terbitan, dan melakukan konversi ke dalam format pdf. Sehingga tahap ini author tinggal mencermati kembali naskah dalam bentuk pdf tersebut. Jika sudah sepakat author kembali menyatakan bahwa naskah dalam bentuk pdf tadi bisa diteruskan dengan menyatakan complete. Selanjutnya tinggal menunggu naskah tersebut dipublikasikan.

Lima tahapan di atas merupakan langkah - langkah yang harus dilakukan seorang author yang melakukan submit naskah. Sehingga dapat diambil kesimpulan bahwa author bukan hanya mengirimkan naskah kemudian menunggu saja kapan naskah akan dipublikasikan. Hal tersebut dapat dilakukan jika pengelola jurnal kekurangan naskah sehingga rela menggantikan author melakukan perbaikan sampai dengan proses terakhir selesai.

Berikut ini adalah gambar dimana dilakukan transfer knowledge yang fokus pada submit artikel pada jurnal online berbasis OJS. 


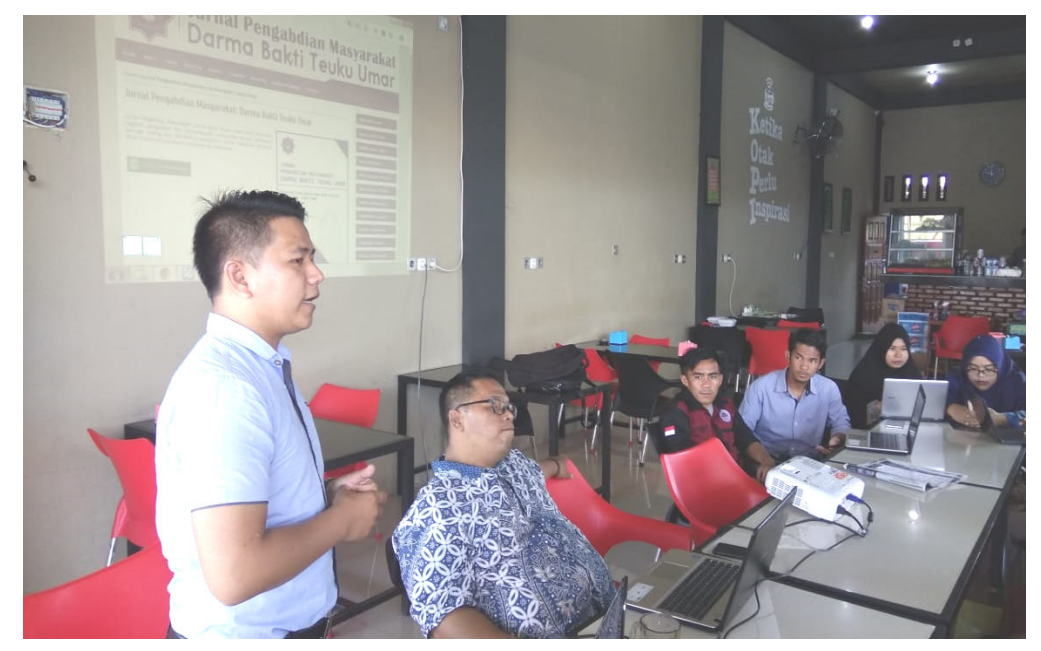

Gambar 3: Materi Pengenalan Jurnal Online di UTU 2020

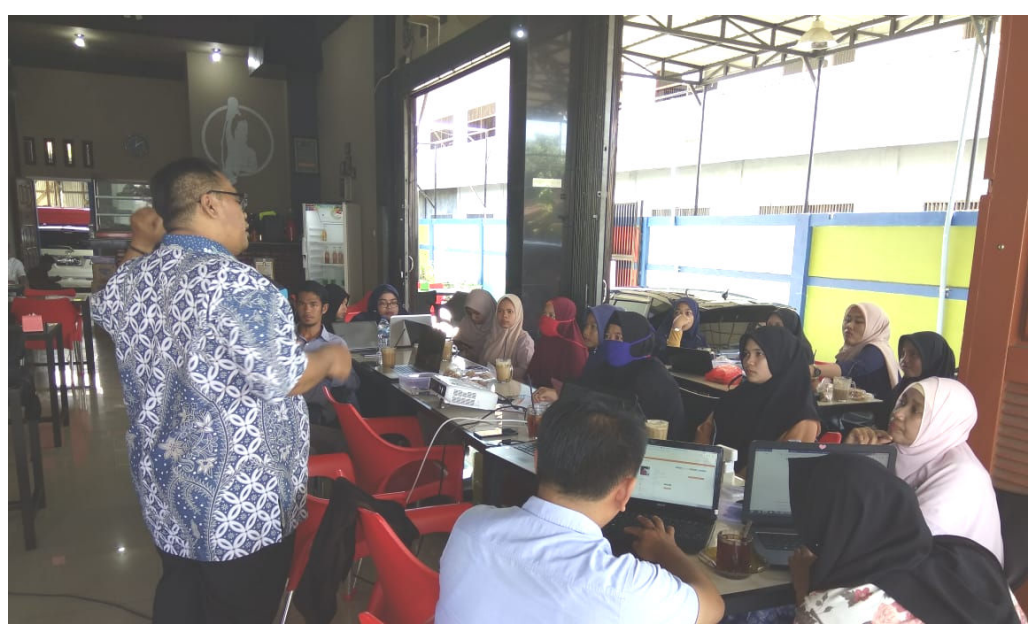

Gambar 4: Materi Submit Artikel Pada OJS 2020

Materi ke empat, mengenai peer review yang disampaikan oleh Arfriani Maifizar. Inti dari materi ini adalah bahwa sebuah naskah yang sudah masuk di akun section editor akan dikirimkan ke akun seorang reviewer berdasarkan keahliannya. Seorang reviewer bisa jadi tidak akan mengenali penulis naskah, lantaran identitas penulis sudah dihilangkan oleh section editor. Dengan dihilangkan identitas ini diharapkan reviewer tidak terganggu dengan identitas seorang author yang bisa jadi lebih terkenal dari dirinya dalam bidang ilmu yang ditekuninya. Pemberian materi ini berkaitan dengan memotivasi dan meningkatkan kepercayaan diri 
anggota Ipelmas dalam menulis karya ilmiah.

Materi terakhir adalah pengenalan jurnal mahasiswa. Inti materi ini adalah kebutuhan prodi prodi tentang publikasi ilmiah dari sisi mahasiswa. Karena akreditasi ke depan memerlukan publikasi karya ilmiah mahasiswa berdasarkan standar nasional pendidikan tinggi (Permendikbud, nomor 3 tahun 2020). Pentingnya karya ilmiah mahasiswa yang berkualitas terpublish, namun sampai saat ini belum ada jurnal yang mengakomodir karya ilmiah mahasiswa ini. Saat ini karya ilmiah mahasiswa yang berkualitas masih belum banyak yang dipublikasikan, karena jika menggunakan jurnal prodi akan bersaing dengan dosen. Sehingga hanya beberapa saja yang bisa berkolaborasi dengan dosen untuk menjembatani hal itu.

Sebagai sesi terakhir dilakukan tanya jawab dengan semua pemateri. Dari tanya jawab ini secara sekilas dapat ditekankan bahwa peserta sudah mendapatkan pemahaman mengenai submit artikal, peserta juga menguasai tekniknya karena sebelum kegiatan ini peserta sudah melakukan praktik submit. Dengan demikian peserta sudah mengerti pada poin poin mana mengalami kendala dalam proses submit tersebut.

\section{PENUTUP}

Sebagai penutup dapat diambil sebuah kesimpulan bahwa selama proses tanya jawab sudah tampak indikasi penguasaan materi mengenai submit dan kewajiban yang harus dilakukan seorang author. Materi selain teknik submission pada kegiatan inimerupakan penunjang yang memperkaya pemahaman peserta ketika akan mengirimkan naskah yang sesungguhnya.

Tim pemateri mengucapkan terimakasih yang sebesar - besarnya kepada keluarga besar Ipelmas dan juga Prodi Sosiologi yang menjadi media terselenggaranya kegiatan transfer knowledge ini.

\section{DAFTAR PUSTAKA}

Darmalaksana, W. dan Suryana, Y. (2017) 'KORESPONDENSI DALAM PUBLIKASI ILMIAH', Jurnal Perspektif, 1(2), pp. 1-8. doi: http:/ / dx.doi.org/10.15575/jp .v1i2.10.

Hasanah, M. et al. (2019) Laporan Kegiatan Pengabdian Kepada Masyarakat Pelatihan Penggunaan Aplikasi Zootero Untuk Pembuatan Sitasi dan Daftar Pustaka Pada Mahasiswa Pendidikan IPS FKIP Universitas Lambung Mangkurat. Banjarmasin. doi: 10.1145/2505515.2507827.

Hazrati, K. (2017) 'Peran 
perpustakaan sebagai media komunikasi ilmiah', Jurnal Iqra', 11(1), pp. 29-47. Available at: https://core.ac.uk/ download /pdf/266976609.pdf.

Herlawati, H. (2017) 'Algoritma Hungarian Dalam Menentukan Pembagian Tugas Sebagai Manajemen Jurnal Pada Open Journal System(OJS)', INFORMATION SYSTEM FOR EDUCATORS AND PROFESSIONALS, 2(1), pp. 83-94. Available at: http:/ / ejournalbinainsani.ac.id/index.php/IS $\mathrm{BI} /$ article/view/674/553.

http:// sinta.ristekbrin.go.id/ (2020) No Title. Available at: http:// sinta.ristekbrin.go.id/a ffiliations / detail?id=521\&view =overview.

Mathar, T. (2017) Proses Submit Artikel dan Peer-Reviewer pada Jurnal Elektronik (OJS). Makassar. Available at: http:// repositori.uinalauddin.ac.id/5711/1/Proses Submit Artikel dan Proses Peer-Reviewer.pdf.

Pahmi, P. et al. (2018) 'Pelatihan Penggunaan Mendeley Untuk Referensi Dalam Menulis Karya Ilmiah Bagi Guru Sma Handayani Pekanbaru', Jurnal Pengabdian UntukMu NegeRI, 2(2), pp. 35-39. doi: 10.37859/jpumri.v2i2.849.

Permendikbud (2020) Peraturan
Menteri Pendidikan dan Kebudayaan Republik Indonesia Nomor 3 tahun 2020 Tentang Standar Nasional Pendidikan Tinggi. Indonesia.

Prayogo, Y. (2020) UI Geser UGM, Inilah 50 Besar Peringkat Universitas di Indonesia Versi Webometrics. Available at: https:/ / www.kalderanews.co m/2020/02/ui-geser-ugminilah-50-besar-peringkatuniversitas-di-indonesia-versiwebometrics/ (Accessed: 4 June 2020).

Rahmawati (2018), 'ANALISIS INDEKSASI JURNAL ILMIAH BIDANG PERTANIAN INDONESIA DI DOAJ', Jurnal Pustaka Budaya, 5(2), pp. 36-41. Available at: https://journal.unilak.ac.id/in dex.php/pb/article/view / 167 0/1130.

Rahmawati, C. et al. (2018) 'Pelatihan Software Mendeley Dalam Peningkatan Kualitas Artikel Ilmiah Bagi Dosen', Jurnal Pengabdian Kepada Masyarakat, 8(1), p. 30. doi: 10.30999/jpkm.v8i1.200.

Sudiar, N. and Latiar, H. (2020) 'Indeksasi Jurnal di Lingkungan Universitas Lancang Kuning', Lentera Pustaka: Jurnal Kajian Ilmu Perpustakaan, Informasi dan Kearsipan, 6(1), pp. 37-46. doi: https://doi.org/10.14710/lenp ust.v6i1.27284. 